Volume 1 Nomor 22021

http://journal.febubhara-sby.org/bharanomics ISSN (Online): 2774-7190

\title{
Pengaruh Modal, Tenaga Kerja, Pesaing dan Inovasi terhadap Pendapatan Pengrajin Reog di Ponorogo
}

\author{
* Fathul Khoiriyah, Nurul Imamah, Abdul Fattah \\ Fakultas Ekonomi dan Bisnis Universitas Bhayangkara Surabaya, Indonesia
}

DOI: 10.46821/bharanomics.v1i2.154

\begin{abstract}
Abstrak
Penelitian ini bertujuan untuk menganalisis pengaruh Modal, Tenaga Kerja, Pesaing dan Inovasi terhadap pendapatan pengrajin Reog di Ponorogo.Dalam melakukan penelitian ini metode survey, data yang di peroleh berupa data primer yang diperoleh dari pengrajin di Ponorogo sebanyak 25 responden.Hasil penelitian ini menunjukkan bahwa terdapat pengaruh simultan dari variable Modal, Tenaga Kerja, Pesaing dan Inovasi terhadap pendapatan pengrajin Reog di Ponorogo.Secara parsial, variabel Modal dan Tenaga Kerja berpengaruh terhadap pendapatan pengrajin Reog di Ponorogo. Sedangkan variabel yang dominan terhadap pendapatan pengrajian Reog adalah Modal dengan angka terbesar sebesar 69,9\% dari seluruh besarnya pengaruh.
\end{abstract}

Kata kunci: Modal, Tenaga Kerja, Pesaing, Inovasi, Pendapatan

\begin{abstract}
:
This study aims to analyze the effect of Capital, Labor, Competitors and Innovation on the income of Reog craftsmen in Ponorogo. In conducting this research survey method, the data obtained in the form of primary data obtained from craftsmen in Ponorogo were 25 respondents. The results of this study indicate that there is a simultaneous influence of the Capital, Labor, Competitors and Innovation variables on the income of Reog craftsmen in Ponorogo. Partially, the Capital and Labor variables affect the income of Reog craftsmen in Ponorogo. While the dominant variable on Reog's payroll income is Capital with the largest figure of $69.9 \%$ of the total influence.
\end{abstract}

Keywords: Capital, Labor, Competitors, Innovation, Revenue

\section{PENDAHULUAN}

Ponorogo merupakan salah satu kabupetan di Jawa Timur yang mayoritas penduduknya bermata pencaharian petani untuk menyambung hidup masyarakatnya. Tetapi tidak hanya sebagai petani,Ponorogo Juga terkenal dengan industry kecil untuk perekenomian mereka.salah satu nya adalah pengrajin Reog, Ponorogo terkenal dengan kesenian Reog yang di hasilkan oleh para pengrajin yang tersebar di beberapa desa di Ponorogo, kesuksesan reog di ponorogo sangat di dukung oleh para pengrajin karena berkat merekalah yang membentuk dan mendesain reog dengan indah dan mempesona. Jumlah pengrajin reog semakin tahun semakin bertambah walaupun tidak dalam angka besar. Data BPS kabuten POnorogo tahun 2007 jumlah pengrajin Reog 16 Pengrajin, mengalami kenaikan pada tahun 2013 yaitu sejumlah 24 pengrajin reog,pada tahun 2016 terdapat 31 pengrajin reog di Ponorogo. Dengan semakin terkenalnya Reog di seluruh Indonesia bahkan di manca Negara maka Perkembangan ekonomi di Ponorogo semakin maju.

Secara umum, permasalahan yang dihadapi oleh para pengrajin reog adalah pendapatan yang tidak menentu yang terkadang bisa meningkat dan menurun, Tenaga kerja dalam pembuatan reog yang masih belum banyak yang menekuni, Mahal dan

*Corresponding Author:

Hal: 61-66

Email: fathulkhoiriyah4@gmail.com 
sulitnya memperoleh bahan baku untuk menghasilkan output Reog dan komponen pendukung lainnya, persaingan yang sangat ketat dalam pemasaran produk maupun persaingan harga juga termasuk permasalahan dalam pendapatan para pengrajin.

Dari uraian latar belakang masalah, maka rumusan masalah dalam penelitian ini adalah. Apakah Modal, Tenaga Kerja, Pesaing dan Inovasi secara simultan berpengaruh signifikan terhadap pendapatan pengrajin Reog di Ponorogo?. Apakah Modal, Tenaga Kerja, Pesaing dan Inovasi secara parsial berpengaruh signifikan terhadap pendapatan pengrajin Reog di Ponorogo?. Manakah diantara variabel Modal, Tenaga Kerja, Pesaing dan Inovasi yang berpengaruh dominan terhadap pendapatan pengrajin reog di Ponorogo?

\section{TINJAUAN PUSTAKA}

\section{Pendapatan (Y)}

Menurut Nafarin ( 2006:15), Pendapatan adalah Arus masuk harta dari kegiatan perusahaan menjual barang dan jasa dalam suatu periode yang mengakibatkan kenaikan modal yang tidak berasal dari kontribisi penanaman modal. Pendapatan dari kegaiatan perusahaan dagang dasarnya adalah suatu proses mengenai arus penciptaan barang dan jasa oleh perusahaan selama jangka waktu tertentu.

\section{Modal}

Menurut Sawir (2005 : 129) mengemukakan modal kerja adalah keseluruhan aktiva lancar yang dimiliki perusahaan atau dapat pula dimaksudkan sebagai dana yang harus tersedia untuk membiayai kegiatan operasi perusahaan sehari - hari.

\section{Tenaga Kerja}

Mulyadi (2003) juga memberikan definisi tenaga kerja sebagai penduduk dalam usia kerja (berusia 15-64 tahun) atau jumlah seluruh penduduk dalam suatu Negara yang dapat memproduksi barang dan jasa jika ada permintaan terhadap tenaga mereka, dan jika mereka mau berpartisipasi dalam aktifitas tersebut

\section{Pesaing}

Pesaing adalah salah satu faktor yang menentukan tingkat pendapatan pesaing menghasilkan dan menjual barang yang serupa dengan produk kita dan mengejar mangsa pasar yang sama. Perusahaan Perlu terus membandingkan produk, harga, distribusi, promosi dengan pesaingnya Basrowi (2011:9-10).

\section{Inovasi}

Inovasi produk seharusnya mampu memberikan nilai tambah dibanding produk sejenis (keunggulan produk) sehingga dapat menjadikan perusahaan memiliki keunggulan dibandingkan dengan pesaingnya Lukas dan Ferrell (2000:240).

\section{METODE PENELITIAN}

Metode yang digunakan dalam penelitian ini adalah metode kuantitatif, teknik pengambilan data melalui survey.Metode pengambilan sampel yang digunakan dalam penelitian ini adalah teknik non probability sampling.Jenis dari teknik non probability sampling yang digunakan dalam penelitian ini adalah sampling jenuh. 
Bharanomics

Vol. 1 No. 22021

Fathul Khoiriyah dkk., Pendapatan Pengrajin Reog di Ponorogo

Sampling jenuh adalah teknik penentuan sampel bila semua anggota populasi digunakan sebagai sampel

Analisis data berfungsi untuk menyimpulkan hasil dari penelitian. Analisis yang digunakan untuk menjawab permasalahan atau hipotesis dalam penelitian ini adalah analisis regresi linier berganda dengan cara menguji secara statistik dan menggunakan program SPSS (Statistic Product and Service Solution) for window version 25.0. Hasil analisis dapat digunakan sebagai tolak ukur agar mengetahui seberapa besar pengaruh seluruh variabel bebas terhadap variabel terikat.

\section{HASIL DAN PEMBAHASAN}

\section{Hasil Analisis Statistik Deskriptif}

Berdasarkan pada tabel 1, maka dapat disimpulkan bahwa variabel modal (X1) mempunyai nilai minimum sebesar Rp 5.000.000, nilai maksimum sebesar Rp 25.000.000, nilai rata-rata sebesar $\mathrm{Rp} 12.460 .000$, dan standard deviasi sebesar 4821652,552. Variabel tenaga kerja (X2) mempunyai nilai minimum sebesar 2, nilai maksimum sebesar 6, nilai rata-rata sebesar 3,44, dan standard deviasi sebesar 1,294. Variabel pesaing (X3) mempunyai nilai minimum sebesar 1, nilai maksimum sebesar 3 , nilai rata-rata sebesar 2,08, dan standard deviasi sebesar 0,759. Variabel inovasi (X4) mempunyai nilai minimum sebesar 1 , nilai maksimum sebesar 2 , nilai rata-rata sebesar 1,52, dan standard deviasi sebesar 0,510. Variabel pendapatan pengrajin reog (Y) mempunyai nilai minimum sebesar Rp 15.000.000, nilai maksimum sebesar Rp 60.000.000, nilai rata-rata sebesar $\mathrm{Rp} 35.680 .000$, dan standard deviasi sebesar 12595369,520 .

\section{Uji Normalitas}

Berdasarkan Tabel 2, maka dapat dijelaskan bahwa semua variabel mempunyai asymp.sig. (2-tailed) > 0,05 sehingga dapat disimpulkan bahwa model tersebut dikatakan normal.

Tabel 1

Analisis Statistik Deskriptif

\begin{tabular}{llllll}
\hline & $\mathrm{N}$ & Minimum & Maximum & Mean & Std. Deviation \\
\hline Modal & 25 & 5000000 & 25000000 & 12460000.00 & 4821652.552 \\
Tenaga Kerja & 25 & 2 & 6 & 3.44 & 1.294 \\
Pesaing & 25 & 1 & 3 & 2.08 & .759 \\
Inovasi & 25 & 1 & 2 & 1.52 & .510 \\
Pendapatan Pengrajin 25 & 15000000 & 60000000 & 35680000 & 12595369.520 \\
Reog & & & & & \\
\hline
\end{tabular}

Sumber: Data Diolah, 2020

Tabel 2

Hasil Uji Kolmogorov-Smirnov

\begin{tabular}{cc}
\hline & Unstandardized Residual \\
\hline $\mathrm{N}$ & 25 \\
Asymp. Sig. (2-tailed) & .200 \\
\hline
\end{tabular}

Sumber: Data Diolah, 2020 
Tabel 3

Hasil Koefisien Regresi

Coefficients $^{\mathrm{a}}$

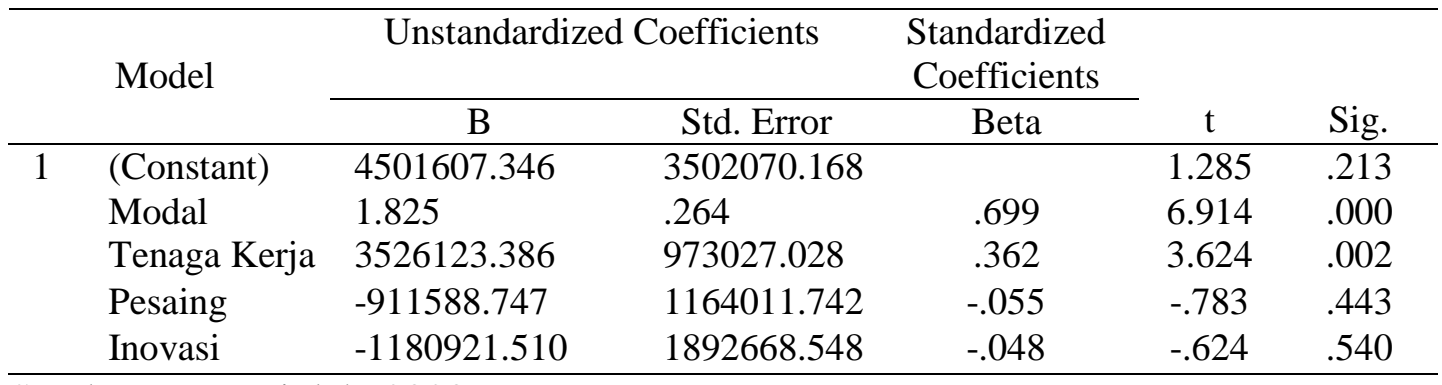

Sumber: Data Diolah, 2020

\section{Tabel 4}

Uji F

ANOVA ${ }^{\mathrm{a}}$

\begin{tabular}{llccccc}
\hline & Model & Sum of Squares & df & Mean Square & F & Sig. \\
\hline 1 & Regression & 3508151686605222.00 & 4 & 877037921651305.50 & 58.608 & $.000^{\mathrm{b}}$ \\
& Residual & 299288313394777.300 & 20 & 14964415669738.865 & & \\
& Total & 3807439999999999.50 & 24 & & & \\
\hline
\end{tabular}

Sumber: Data Diolah, 2020

\section{Analisis Regresi Linier Berganda}

Berdasarkan Tabel 3, maka dapat dibuat model persamaan regresi sebagai berikut.

$\mathrm{Y}=\mathrm{a}+\mathrm{b}_{1} \mathrm{X}_{1}+\mathrm{b}_{2} \mathrm{X}_{2}+\mathrm{b}_{3} \mathrm{X}_{3}$

$Y=4501607,346+1,825 X_{1}+3526123,386 X_{2}-911588,747 X_{3}-1180921,510 X_{4}$

\section{Uji t (Uji Parsial)}

Berdasarkan Tabel 3 diatas dapat disimpulkan bahwa nilai sig. $<0,05$ yaitu 0,000 < 0,05 untuk variabel modal (X1) maka H0 ditolak dan H1 diterima. Sehingga dapat diartikan bahwa secara parsial terdapat pengaruh signifikan antara variabel modal (X1) terhadap pendapatan pengrajin $\operatorname{reog}(\mathrm{Y})$.

Variabel tenaga kerja mempunyai nilai sig. $<0,05$ yaitu $0,002<0,05$ maka H0 ditolak dan H1 diterima. Sehingga dapat diartikan bahwa secara parsial terdapat pengaruh signifikan antara variabel tenaga kerja (X2) terhadap pendapatan pengrajin $\operatorname{reog}(\mathrm{Y})$.

Variabel pesaing mempunyai nilai sig. $>0,05$ yaitu $0,443>0,05$ maka $\mathrm{H} 0$ diterima dan H1 ditolak. Sehingga dapat diartikan bahwa secara parsial tidak terdapat pengaruh signifikan antara variabel pesaing (X3) terhadap pendapatan pengrajin $\operatorname{reog}(\mathrm{Y})$.

Variabel inovasi mempunyai nilai sig. > 0,05 yaitu 0,540 > 0,05 maka H0 diterima dan H1 ditolak. Sehingga dapat diartikan bahwa secara parsial tidak terdapat pengaruh signifikan antara variabel inovasi (X4) terhadap pendapatan pengrajin reog (Y). 


\section{Tabel 5}

\section{Hasil Koefisien Determinasi}

Model Summary

\begin{tabular}{lcccc}
\hline Model & R & R Square & Adjusted R Square & Std. Error of the Estimate \\
\hline 1 & $.960^{\mathrm{a}}$ & .921 & .906 & 3868386.701
\end{tabular}

Sumber: Data Diolah, 2020

\section{Uji F (Simultan)}

Berdasarkan pada Tabel 4, maka dapat diperoleh keputusan bahwa Tolak H0 dimana nilai sig. $<\alpha(0,000<0,05)$. Ini berarti bahwa variabel independen (modal, tenaga kerja, pesaing, dan inovasi) secara simultan berpengaruh terhadap variabel dependen (pendapatan pengrajin reog).

\section{Koefisien Determinasi $\left(\mathbf{R}^{2}\right)$}

Berdasarkan Tabel 5, menunjukkan bahwa besarnya nilai koefisien determinasi (R2) sebesar 0,921. Hal ini menunjukkan bahwa besarnya kontribusi variabel modal (X1), tenaga kerja (X2), pesaing (X3), dan inovasi (X4) adalah sebesar 92,1\%, sedangkan sisanya $7,9 \%$ dikarenakan oleh variabel bebas lain yang tidak termasuk dalam model dalam penelitian ini.

\section{SIMPULAN}

Berdasarkan hasil analisis dan pembahasan maka dapat disimpulkan sebagai berikut. Hasil penelitian ini menunjukan bahwa Variabel Modal, Tenaga Kerja, secara parsial berpengaruh terhadap pendapatan pengrajin reog di Ponorogo. Sedangkan Pesaing dan Inovasi tidak berpengaruh terhadap pendapatan pengrajin. Hasil penelitian ini menunjukan bahwa Variabel bebas (modal, tenaga kerja, pesaing, dan inovasi) berpengaruh secara simultan atau bersama-sama terhadap pendapatan pengrajin reog di Ponorogo. Maka dapat disimpulkan bahwa jika modal, tenaga kerja, pesaing, dan inovasi meningkatkan pendapatan pengrajin reog secara bersama-sama. dengan nilai F hitung sebesar 58,608 dengan sig. sebesar 0,000. Karena sig. kurang dari 0,05, maka H4 diterima. Jadi, dapat disimpulkan bahwa modal, tenaga kerja, pesaing, dan inovasi berpengaruh signifikan terhadap pendapatan pengrajin reog. Hasil penelitian ini menunjukan bahwa Variabel bebas modal mempunyai pengaruh dominan terhadap pendapatan pengrajin reog di ponorogo dibandingkan dengan variable Tenaga Kerja, Pesaing, dan Inovasi. pendapatan pengrajin reog dengan sumbangan terbesar sebesar $69,9 \%$ dari seluruh besarnya pengaruh.

\section{DAFTAR PUSTAKA}

Mamang Sengaji, Sopiah, Metode Penelitian Pendakatan Praktis Dalam Penelitian, ed 1 Yoyakarta: Andi, 2010.

Nasir. M, Metode Penelitian, Bogor: Ghalia Indonesia, 2005.

Pitana I Gde Dan I Kutut Surya Duarta. Pengentar Ilmu Pariwisata. Yogyakarta: Andy. 2009. 
Bharanomics

Vol. 1 No. 22021

Fathul Khoiriyah dkk., Pendapatan Pengrajin Reog di Ponorogo

Husaini Usman, Purnomo Setiady Akbar, Metodologi Penelitian Sosial, Jakarta: PT Bumi Aksara, 2004.

Imam Suprayoga, Tabroni, Metodologi Penelitian Sosial-Agama, Bandung: PT. Remaja Rosdakarya, 2003.

Irawan Soeharto, Metode Penelitian Sosial Suatu Teknik Penelitian Bidang Kesejahteraan Sosial dan Ilmu Sosial Lainnya, Bandung: Remaja Rosdakarya, 2011. 